\title{
Cancer antigen 125 level is determined by tricuspid regurgitation among patients with stable systolic heart failure
}

\author{
Stabil sistolik kalp yetersizliği hastalarında kanser antijen 125 düzeyi triküspit \\ yetersizliği ile belirlenmektedir
}

Hakkı Kaya*, Hasan Yücel, Ali Zorlu

Cardiology Clinic (H. Kaya, MD), Sivas Numune Hospital, TR-58040 Sivas, Department of Cardiology (Assist. Prof. H. Yücel, MD, Assist. Prof. A. Zorlu, MD), Cumhuriyet University School of Medicine, TR-58140 Sivas

\begin{abstract}
Aim. Cancer antigen 125 (CA-125) is a soluble glycoprotein with high molecular weight. Recently, increased serum CA-125 levels were also documented in patients with heart failure (HF). We aimed to show what factors influence serum levels of CA-125 among patients with chronic systolic HF. Method. Patients, who had chronic systolic HF with echocardiographically determined ejection fraction $(\mathrm{EF})<45 \%$ were enrolled into final analysis $(n=56)$. CA-125 levels were classified into two as those with normal $(<35 \mathrm{U} / \mathrm{mL})$ and high levels $(\geq 35 \mathrm{U} / \mathrm{mL})$. Results. Patients with Right ventricular (RV) dilatation had significantly higher CA-125 levels compared to those without RV dilatation. Besides, patients with RV dilatation had higher systolic pulmonary artery pressure (SPAP) levels compared to those without. Patients with high CA-125 levels had more frequent RV dilatation, higher pulmonary artery pressure, more severe tricuspid regurgitation. Tricuspid regurgitation was the only significant predictor of high CA-125 levels in patients with stable chronic systolic HF. Conclusion. It was shown in this study that tricuspid regurgitation was the only independent predictor of high CA-125 levels among patients with chronic stable systolic HF.
\end{abstract}

Keywords: CA-125, heart failure, right ventricle, tricuspid regurgitation

Özet

Amaç. Kanser antijen 125 (CA-125) yüksek molekül ağırlıklı çözülebilir bir glikoproteindir. Son yıllarda kalp yetersizliği (KY) hastalarında serum CA-125 düzeylerinin arttığı gösterilmiştir. Bu çalışmada kronik sistolik KY hastalarında serum CA-125 düzeylerini etkileyen faktörleri göstermeyi amaçladık. Yöntem. Sistolik KY ekokardiyografik olarak gösterilmiş, ejeksiyon fraksiyon $<\% 45$ olan hastalar son analize dahil edildi $(n=56)$. CA-125 düzeyleri normal $(<35$ $\mathrm{U} / \mathrm{mL})$ ve yüksek $(\geq 35 \mathrm{U} / \mathrm{mL})$ olarak iki gruba ayrıldı. Bulgular. Sağ ventrikül (Sağ V) dilatasyonu olan hastalarda Sağ V dilatasyonu olmayanlara göre CA-125 düzeyleri anlamlı olarak daha yüksekti. Bunun yanında Să̆ V dilatasyonu olan hastalarda olmayanlara göre sistolik pulmoner arter basıncı (SPAB) değerleri daha yüksekti. CA-125 düzeyleri yüksek olan hastalarda Sağ V dilatasyonu daha sık, SPAB daha yüksek, triküspit yetmezliği daha ciddiydi. Stabil kronik sistolik KY hastalarında sadece triküspit yetmezliği, yüksek CA-125 düzeyini predikte etmektedir. Sonuç. $\mathrm{Bu}$ çalışma göstermektedir ki stabil kronik kalp yetmezliği hastalarında, triküspit yetersizliği, yüksek CA-125 düzeylerinin bağımsız prediktörüdür.

Anahtar sözcükler: CA-125, kalp yetersizliği, sağ ventrikül, triküspit yetmezliği

Geliş tarihi/Received: April 08, 2014; Kabul tarihi/Accepted: May 22, 2014

*Corresponding author:

Dr. Hakkı Kaya, Kardiyoloji Kliniği, Sivas Numune Hastanesi, TR-58030 Sivas. E-mail: drhakkikaya84@gmail.com 


\section{Introduction}

Cancer antigen 125 (CA-125) is a soluble glycoprotein with high molecular weight [1]. Not only epithelial ovarian tumors are known to produce this substance but also normal cells of different tissues, such as pericardium, pleura, peritoneum and Mullerian epithelium could produce it in response to various stimuli, including mechanical stress, and inflammation [1-3]. Serum CA-125 levels are also increased in other malignancies and non-malignant conditions [3, 4]. Recently, increased serum CA-125 levels were also documented in patients with heart failure (HF) along with other biomarkers [5, 6]. Right ventricular (RV) dysfunction complicates the course of HF, and hence, influences prognosis [7]. However, association between right heart chambers and CA-125 in systolic heart failure was not investigated thoroughly. We investigated the impacts of RV functions on the serum levels of CA-125 among patients with chronic stable systolic HF.

\section{Material and method}

Four hundred consecutive patients with at least one available CA-125 assays scanned from the registry system of our hospital between January 2006 and August 2009. One hundred patients were noticed to have the diagnosis of HF additionally. Fifty six patients (40 male, 16 female), who had chronic stable systolic HF (left ventricular ejection fraction (LVEF) $<45 \%$ ) were enrolled into final analysis. Patients, who were diagnosed with malignancy $(n=11)$, patients with heart failure decompensations during the measurements of CA-125 (within one month) $(\mathrm{n}=12)$, were excluded from the analysis. Eleven patients with available CA-125 level were noticed to have HF with preserved EF (six patients with acute de novo HF). CA-125 levels of 10 patients had been measured in a time period, which was far from any echocardiographic evaluation. Hence, these patients were not included.

CA-125 levels above than $35 \mathrm{U} / \mathrm{mL}$ were classified as high according to our laboratory reference limits and a previous studies [6]. None of the patients were suffered from acute decompensation of chronic HF during CA-125 measurements. All echocardiograms were being performed within two weeks of the measurement of CA-125 via Vivid 7 system (GE Medical System) with 2.5-5 Mhz probes. Digital records of echocardiographic examinations were evaluated offline by at least two experienced echocardiographer (cardiac sonographer or cardiologist). Ejection fraction was calculated by modified Simpson's method. Right ventricular dimensions were evaluated according to the most recent guideline [8], and hence, midcavity and/or basal RV diameter above and below reference range in the apical 4-chamber view at end diastole were considered. Those with above reference limit in any of the above mentioned measurements were classified as RV dilatation. Valvular regurgitations, namely mitral and tricuspid regurgitation were quantified according to recent guideline, and categorized as trivial/mild/moderate/severe [8]. Systolic pulmonary artery pressure (SPAP) was calculated as shown previously [9]. Systolic pulmonary artery pressure was classified as normal $(<25 \mathrm{mmHg})$ and high $(\geq 25$ $\mathrm{mmHg}$ ). Left atrium (LA) size was classified as normal and enlarged according to reference limits of the most recent guideline [8]. Approval from the ethics committee was obtained for investigation of large cohort of patients with heart failure retrospectively.

\section{Statistical analysis}

Parametric data were expressed as mean \pm standard deviation, and categorical data as percentages. SPSS 15.0 (SPSS, Inc., Chicago, Illinois) was used to perform statistical analysis. Independent parameters were compared via Independent sample's t test. Categorical data were evaluated by chi square test as appropriate. Correlations were evaluated by Pearson's correlation test. Multivariable logistic regression was used to evaluate independent parameters affecting high CA-125 levels. A p value below than 0.05 was adopted significant. 


\section{Results}

Mean age of the whole study group were $70 \pm 9$ years and mean LVEF was $30 \pm 8 \%$. All patients had chronic systolic heart failure with dilated left ventricles without a recent decompensation (>6 months previously). All patients had NYHA Class II-III symptoms. Results are summarized in Table 1.

Table 1. Patients with and without Right ventricular dilatation.

\begin{tabular}{llll}
\hline & $\begin{array}{l}\text { Those with RV } \\
\text { dilatation }(\mathbf{n = 2 9})\end{array}$ & $\begin{array}{l}\text { Those without RV } \\
\text { dilatation }(\mathbf{n = 2 7})\end{array}$ & p \\
\hline Ejection fraction (\%) & $29 \pm 9$ & $32 \pm 7$ & 0.1 \\
CA-125 level (U/mL) & $148 \pm 132$ & $27 \pm 25$ & $<0.001$ \\
Age (years) & $72.5 \pm 10.4$ & $68.1 \pm 8.5$ & 0.89 \\
Systolic pulmonary artery pressure (mmHg) & $40 \pm 15$ & $20 \pm 6$ & $<0.001$ \\
LV dimension (diastole, mm) & $51.1 \pm 7.4$ & $49.1 \pm 7.1$ & 0.100 \\
Mitral regurgitation (trivial/mild/moderate/severe) & $1 / 17 / 9 / 2$ & $3 / 20 / 4 / 0$ & 0.165 \\
Tricuspid regurgitation (trivial/mild/moderate/severe) & $0 / 10 / 16 / 3$ & $15 / 12 / 0 / 0$ & $<0.001$ \\
NYHA Class II/III & $9 / 20$ & $14 / 13$ & 0.114 \\
Creatinine (mg/dL) & $1.3 \pm 0.4$ & $1.4 \pm 0.9$ & 0.584 \\
Hemoglobin (gr/dL) & $12.8 \pm 2.1$ & $13.1 \pm 2.5$ & 0.636 \\
Sex (male\&female) & $20 \& 9$ & $20 \& 7$ & 0.672 \\
Hypertension & $14(48.3 \%)$ & $16(59.3 \%)$ & 0.410 \\
Diabetes mellitus & $9(31 \%)$ & $9(33.3 \%)$ & 0.854 \\
\hline
\end{tabular}

High CA-125 levels were positively correlated with SPAP levels $(r=0.476, p<0.001)$. Patients with RV dilatation had significantly higher CA-125 levels compared to those without RV dilatation $(148 \pm 132 \mathrm{U} / \mathrm{mL}$ vs. $27 \pm 25 \mathrm{U} / \mathrm{mL}, \mathrm{p}<0.001)$. CA-125 levels were positively correlated with severity of tricuspid regurgitation $(\mathrm{r}=0.693, \mathrm{p}<0.001)$. Moderate to severe tricuspid regurgitation was associated with 33 fold increased risk of to be high CA-125 level (3.9-277.8; 95\% CI). Moderate to severe tricuspid regurgitation predicted high CA-125 level with a sensitivity of $58.1 \%$, specificity of $96 \%$. However, high CA-125 level was not associated with EF (Table 2). Factors having significant association with high CA-125 levels were enrolled into multivariable logistic regression analysis. It was found that tricuspid regurgitation was the only independent predictor of high CA-125 levels (1.15-47.05, $\mathrm{p}=0.035, \operatorname{Exp}(\mathrm{B})=7.371 ; 95 \% \mathrm{CI})$.

Table 2. Patients with and without high cancer antigen 125 level.

\begin{tabular}{llll}
\hline & $\begin{array}{l}\text { Patients with high } \\
\text { CA-125 level }(\mathbf{n = 3 1})\end{array}$ & $\begin{array}{l}\text { Patients with normal } \\
\text { CA-125 level }(\mathbf{n = 2 5})\end{array}$ & p \\
\hline Ejection fraction (\%) & $30 \pm 9$ & $31 \pm 7$ & 0.558 \\
Age (years) & $70.9 \pm 10.9$ & $69.7 \pm 8.1$ & 0.645 \\
High systolic pulmonary artery pressure $(>25 \mathrm{mmHg})$ & $22(71 \%)$ & $6(24 \%)$ & 0.001 \\
LV dimension (diastole, mm) & $51.4 \pm 7.4$ & $49.2 \pm 7.1$ & 0.075 \\
Mitral regurgitation (trivial/mild/moderate/severe) & $1 / 19 / 9 / 2$ & $3 / 18 / 4 / 0$ & 0.225 \\
Tricuspid regurgitation (trivial/mild/moderate/severe) & $2 / 11 / 15 / 3$ & $13 / 11 / 1 / 0$ & $<0.001$ \\
NYHA Class II/III & $10 / 21$ & $13 / 12$ & 0.135 \\
Presence of RV dilatation & $5(80.6 \%)$ & $4(16 \%)$ & $<0.001$ \\
Sex (male\&female) & $20 \& 11$ & $20 \& 5$ & 0.197 \\
Presence of left atrial dilatation & $26(83.9 \%)$ & $19(76 \%)$ & 0.514 \\
Creatinine (mg/dL) & $1.3 \pm 0.5$ & $1.3 \pm 0.9$ & 0.951 \\
Hemoglobin (gr/dL) & $12.5 \pm 2.3$ & $13.4 \pm 2.2$ & 0.159 \\
Hypertension & $16(51.6 \%)$ & $14(56 \%)$ & 0.954 \\
Diabetes mellitus & $9(29 \%)$ & $9(36 \%)$ & 0.789 \\
\hline
\end{tabular}

\section{Discussion}

Increase in the level of CA-125 has been first identified in the ovarian carcinoma [10]. High levels are observed in other conditions such as lung cancer, gastrointestinal cancer, abdominal military tuberculosis, endometriosis, and pelvic inflammatory disease [10, 13]. CA-125 has been also found to be significantly elevated in patients with chronic congestive heart failure (HF) $[4-7,11]$. Idalou et al. [6] had previously shown that CA125 level was correlated with deceleration time, right atrial pressure, SPAP and pulmonary artery wedge pressure. In the study by Gizzard et al. [12], CA-125 was related 
to many parameters of systolic and diastolic function of the left ventricle. CA-125 was suggested as an emerging marker of poor survival in this group of patients [13]. However, those studies also included those with acute decompositions, which could disable accurate reasoning in the setting of acute congestion, which is known to influence CA-125 level [14]. Besides, RV dilatation and tricuspid regurgitation were not separated from other potential confounders. Actually, potential role of right side of the heart in the plasma levels of CA-125 has not been searched in detail so far except case reports [15-16]. In a very recent study enrolling all comers, it was shown that presence of depressed ejection fraction, presence of right ventricular dilatation and presence of pericardial effusion were independent predictors of high CA-125 levels [17] further supporting the notion that RV dilatation could be responsible for elevations of CA-125. In our study, though, RV dilatation was associated with high CA-125 levels in the university analysis; it was not independent predictor of high CA-125 levels in the regression equation in the presence of other factors. Hence, RV dilatation until a certain degree (until severe annular dilatation which causes tricuspid leaflets to stay apart) might not be so important in the absence of severe tricuspid regurgitation, which, transits high pressure retrogradely into splanchnic bed. We did not observe any association between NYHA class and CA-125 level in contrast to previous reports $[6,14]$. However, those studies had enrolled patients from every NYHA class, and in contrast, there were only NYHA Class II-III patients in our study. Besides, all were in relatively a stable situation. This might be the reason that we did not observe any influence. In our study, we shown that in a group of patients with stable systolic HF, high CA-125 level was associated with severity of tricuspid regurgitation. Hence, CA-125 might be providing its prognostic role through highpressure influential signals coming from RV.

In terms of limitations, there might be several confounders of the study due its retrospective nature. Several reasons driving rise of CA-125 might be underrepresented. RV sizes and RV function (e.g. Tricuspid Annular Plane Systolic Excursion [TAPSE]) could have been quantified. However, since there were at least three different recordings and measurements of RV enlargement (long axis, midcavitary, annular level), we had to make qualitative measurement considering any one of the two (annular or midcavitary) for dilatation. Besides, there was no patient with severe RV dilatation in the group, probably, those with severe RV dilatation almost never stay stable. Hence, the study underrepresents those with frequent exacerbations, acute decompensations, and inotrope requiring patients. The authors of this study believe that quantitative evaluation of right heart chambers would impact greatly onto the results.

In conclusion; CA-125 levels seemed to be independently associated with severity of tricuspid regurgitation in patients with chronic stable systolic HF. Integrating CA-125 into clinical decision making particularly in those with stable systolic heart failure might have important implications.

\section{References}

1. O'Brien TJ, Animator H, Knish I, Gee M. More than 15 years of CA125: What is known about the antigen, its structure and its function. Int J Biol Markers 1998; 13: 188-95.

2. Barbieri RL, Niloff JM, Bast RC, Scaetzl E, Kistner RW, Knapp RC. Elevated serum concentrations of CA-125 in patients with advanced endometriosis. Fertil Steril 1986; 45: 630-4.

3. Halila H, Stenman UH, Seppälä M. Ovarian cancer antigen CA 125 levels in pelvic inflammatory disease and pregnancy. Cancer 1986; 57: 1327-9.

4. Zacharos ID, Efstathiou SP, Petreli E, Georgiou G, Tsioulos DI, Mastorantonakis SE. The prognostic signi.cance of CA 125 in patients with non-Hodgkin's lymphoma. Eur J Haematol 2002; 69: 221-6.

5. Nagele H, Bahlo M, Klapdor R, Schaeperkoetter D, Rodiger W. CA125 and its relation to cardiac function. Am Heart J 1999; 137: 1044-9. 
6. D'Aloia A, Faggiano P, Aurigemma G, Bontempi L, Ruggeri G, Metra M. Serum levels of carbohydrate antigen 125 in patients with chronic heart failure: Relation to clinical severity, hemodynamic and Doppler echocardiographic abnormalities, and short-term prognosis. J Am Coll Cardiol 2003 21; 41: 1805-11.

7. Damy T, Viallet C, Lairez O, Deswarte G, Paulino A, Maison P. Comparison of four right ventricular systolic echocardiographic parameters to predict adverse outcomes in chronic heart failure. Eur J Heart Fail 2009; 11: 818-24.

8. Lang RM, Bierig M, Devereux RB, Flachskampf FA, Foster E, Pellikka PA. American Society of Echocardiography's Nomenclature and Standards Committee; Task Force on Chamber Quantification; American College of Cardiology Echocardiography Committee; American Heart Association; European Association of Echocardiography, European Society of Cardiology. Recommendations for chamber quantification. Eur J Echocardiogr 2006; 7: 79108.

9. Yock PG, Popp RL. Noninvasive estimation of right ventricular systolic pressure by Doppler ultrasound in patients with tricuspid regurgitation. Circulation 1984; 70: 657-62.

10. Canney PA, Moore M, Wilkinson PM, James RD. Ovarian cancer antigen CA125: A prospective clinical assessment of its role as a tumor marker. $\mathrm{Br} \mathbf{J}$ Cancer 1984; 50: 765-9.

11. Duman D, Palit F, Simsek E, Bilgehan K. Serum carbohydrate antigen 125 levels in advanced heart failure: Relation to B-type natriuretic peptide and left atrial volume. Eur J Heart Fail 2008; 10: 556-9.

12. Vizzardi E, Nodari S, D'Aloia A, Chiari E, Faggiano P, Metra M. CA 125 tumoral marker plasma levels relate to systolic and diastolic ventricular function and to the clinical status of patients with chronic heart failure. Echocardiography 2008; 25: 955-60.

13. Turgut O, Tandogan I, Yilmaz MB, Gul I, Gurlek A. CA125 levels among patients with advanced heart failure: An emerging independent predictor for survival. Int J Cardiol 2009; 13.

14. Kouris NT, Zacharos ID, Kontogianni DD, Goranitou GS, Sifaki MD, Grassos HE. The significance of CA125 levels in patients with chronic congestive heart failure. Correlation with clinical and echocardiographic parameters. Eur J Heart Fail 2005; 7: 199-203.

15. Mathew B, Bhatia V, Mahy IR, Ahmed I, Francis L. Elevation of the tumor marker CA125 in right heart failure. South Med J 2004; 97: 1013-4.

16. Lockhart CJ, McVeigh GE, Harbinson MT. Elevated CA 125 and ascites: Not always malignancy. Ir J Med Sci 2008; 177: 63-6.

17. Yilmaz MB, Zorlu A, Tandogan I. Plasma CA-125 level is related to both sides of the heart: A retrospective analysis. Int J Cardiol 2009; 18. 